Int. J. Electrochem. Sci., 14 (2019) $7281-7292$

\title{
Preparation and Characterization of $\mathrm{Ti} / \mathrm{SnO}_{2}-\mathrm{Sb}$ Electrodes without or with a Platinum Interlayer Using the Polymeric Precursor Method and Thermal Decomposition
}

\author{
Leonardo Salgado ${ }^{1}$, Carolina Blas Pozos ${ }^{2}$,Teresa Zayas $^{3}$, Laura Galicia $^{1}$ \\ ${ }^{1}$ Departamento de Química, Universidad Autónoma Metropolitana Iztapalapa, A.P. 55-534, C.P. \\ 09340 CDMX, México \\ ${ }^{2}$ TESOEM, División de Ingeniería Ambiental, Estado de México, C.P. 56400, México \\ ${ }^{3}$ Postgrado en Ciencias Ambientales y Centro de Química, Instituto de Ciencias. Benemérita \\ Universidad Autónoma de Puebla, A.P. 1613, C.P. 72000, Puebla, México \\ *E-mail: 1sj@xanum.uam.mx or 1salgadoj@gmail.com
}

doi:10.20964/2019.08.71

Received: 9 April 2019 / Accepted: 24 May 2019 / Published: 30 June 2019

$\mathrm{SnO}_{2}-\mathrm{Sb}$ electrodes on a $\mathrm{Ti}$ substrate, prepared without $\left(\mathrm{Ti} / \mathrm{SnO}_{2}-\mathrm{Sb}\right)$ or with a $\mathrm{Pt}$ interlayer $\left(\mathrm{Ti} / \mathrm{Pt} / \mathrm{SnO}_{2}-\mathrm{Sb}\right)$, were prepared using the polymeric precursor method followed by thermal decomposition. The platinum film on titanium (Ti/Pt) was prepared by thermal decomposition of an alcoholic solution of Pt. Scanning electron microscopy (SEM), energy dispersive X-ray spectroscopy (EDS), and elemental mapping were used to characterize the surfaces of $\mathrm{Ti} / \mathrm{Pt}, \mathrm{Ti} / \mathrm{SnO}_{2}-\mathrm{Sb}$, and $\mathrm{Ti} / \mathrm{Pt} / \mathrm{SnO}_{2}$-Sb. The electrochemical characterization of the electrodes was performed using cyclic voltammetry in a $0.5 \mathrm{M} \mathrm{H}_{2} \mathrm{SO}_{4}$ solution. The electroactive area of the electrodes was determined using measurements of the electrosorption hydrogen charge for Ti/Pt and the capacitance of the electric double layer for $\mathrm{Ti} / \mathrm{SnO}_{2}-\mathrm{Sb}$ and $\mathrm{Ti} / \mathrm{Pt} / \mathrm{SnO}_{2}-\mathrm{Sb}$. Tafel slopes for the oxygen evolution reaction (OER) were estimated from polarization curves. The SEM and EDS results obtained from the electrodes prepared with or without a platinum interlayer displayed distinct behaviors. In the absence of Pt, the $\mathrm{SnO}_{2}-\mathrm{Sb}$ coating on titanium formed a compact layer with a good distribution of $\mathrm{Sn}, \mathrm{Sb}, \mathrm{O}$, and a low $\mathrm{Ti}$ content. In the presence of the $\mathrm{Pt}$ coating, $\mathrm{SnO}_{2}-\mathrm{Sb}$ was heterogeneously distributed. The heterogeneous character of the $\mathrm{Ti} / \mathrm{Pt} / \mathrm{SnO}_{2}-\mathrm{Sb}$ film resulted from surface segregation during the calcination process. The voltammetric behaviors of the $\mathrm{SnO}_{2}-\mathrm{Sb}$ electrodes prepared with or without a Pt interlayer displayed similar trends, although the presence of Pt produced a greater electroactive area and shifted the oxygen evolution potential toward less positive values; therefore, the electrocatalytic activity toward the OER was higher compared to the $\mathrm{Ti} / \mathrm{SnO}_{2}-\mathrm{Sb}$ electrode. The Tafel slope estimated for $\mathrm{Ti} / \mathrm{Pt} / \mathrm{SnO}_{2}-\mathrm{Sb}$ is consistent with a mechanism in which $\mathrm{OH}$. generation is the rate controlling step.

Keywords: Electrodes, Ti/Pt, Ti/ $\mathrm{SnO}_{2}-\mathrm{Sb}, \mathrm{Ti} / \mathrm{Pt} / \mathrm{SnO}_{2}-\mathrm{Sb}$, Preparation, Characterization 


\section{FULL TEXT}

(C) 2019 The Authors. Published by ESG (www.electrochemsci.org). This article is an open access article distributed under the terms and conditions of the Creative Commons Attribution license (http://creativecommons.org/licenses/by/4.0/). 